\title{
Perspectives
}

\section{Zika: the new arbovirus threat for Latin America}

\author{
Alfonso J Rodríguez-Morales \\ The Journal of Infection in Developing Countries
}

Key words: Zika; arbovirus; emerging; Latin America.

J Infect Dev Ctries 2015; 9(6):684-685. doi:10.3855/jidc.7230

(Received 06 June 2015 - Accepted 09 June 2015)

Copyright (C) 2015 Rodríguez-Morales. This is an open-access article distributed under the Creative Commons Attribution License, which permits unrestricted use, distribution, and reproduction in any medium, provided the original work is properly cited.

Zika is an arbovirus from the Flaviviridae family (genus flavivirus) that carries the name of a forest close to Kampala, Uganda, where in 1947 it was identified in rhesus monkeys, through a sylvatic yellow fever surveillance network in that country $[1,2]$. It was first isolated in humans in 1952, in Uganda and in Tanzania [1,3].

In 2007, the Yap State, a Federated States of Micronesia, reported the first outbreak of Zika virus in areas different from Africa and Asia [4,5]. Subsequent infections of Zika virus in other Pacific islands were not reported until 2013 when this virus reappeared in French Polynesia and then disseminated throughout the Pacific [4,6]. In January-February 2014 one Zika case was confirmed in Eastern Islands (Rapa Nui National Park, Chile) in the Pacific ocean [7]; then in May 2015, 17 cases were confirmed in three states of Brazil: Bahia (8 cases), Rio Grande do Norte (8 cases) and São Paulo (1 case) [8].

In other countries of Latin America, where the existence of Aedes mosquitoes is endemic and dengue has been transmitted for decades and since the end of 2013 also chikungunya was reported [9], doubts about the ability to control of these arboviral diseases are even greater as the inability of implementing vector control strategies as has been reported in many countries [10]. Thus, it is extremely important to strengthen surveillance, control suspected cases of dengue, chikungunya and now Zika for early integrated detection of cases. More joint efforts from Latin American countries are needed in addition to regional efforts of the Pan American Health Organization to provide and establish guidelines and policies [9]. There are more elements of concern in the current stage of Zika for Latin America, but a call for collaboration and search for health policies must exist, particularly in view of the increasing number of people travelling to and from Latin American countries [9].

Moreover, Zika has a new particularity that has been recently reported: Zika can be sexually transmitted [11,12] in addition to perinatal and transplacental transmission during childbirth and possibly by blood transfusion $[13,14]$.

Zika should be considered an emerging pathogen and a new threat for Latin America. Fortunately, Zika illness to date has been mild and self-limited. Clinical manifestations can be difficult to differentiate from dengue and chikungunya infections [15]. In addition, co-infection with dengue has also been recently reported [16]. The most common symptoms of Zika infection are: maculopapular skin rash that starts on the face or trunk and becomes more diffuse, headaches, low-grade fever, arthralgias, myalgia, and conjunctivitis $[15,16]$.

Prevention of dengue, chikungunya, Zika and other arbovirus, is achieved by vector control and insect bite precautions [15]. Aedes spp. is adapted for indoor and daytime biting in urban areas. They are known to breed in aquatic environments such as small puddles, open water storage containers, and plants that hold water between the leaves and stems. Insect bite precautions (during early morning and late afternoon peak biting times) and vector control should be tailored to known epidemiology [15]. To date, there is no vaccine for the prevention of Zika and a few studies have been carried out on this emerging arbovirus. If Zika follows a pattern similar to the one observed for chikungunya, cocirculation of both and dengue is expectable in the next coming months. 


\section{References}

1. Ioos S, Mallet HP, Leparc Goffart I, Gauthier V, Cardoso T, Herida M (2014) Current Zika virus epidemiology and recent epidemics. Med Mal Infect 44: 302-307.

2. Dick GW, Kitchen SF, Haddow AJ (1952) Zika virus. I. Isolations and serologicalspecificity. Trans R Soc Trop Med Hyg 46: 509-520.

3. Dick GW (1952) Zika virus. II. Pathogenicity and physical properties. Trans RSoc Trop Med Hyg 46: 521-534.

4. Cao-Lormeau VM, Musso D (2014) Emerging arboviruses in the Pacific. Lancet 384: 1571-1572.

5. Duffy MR, Chen TH, Hancock WT, Powers AM, Kool JL, Lanciotti RS, Pretrick M, Marfel M, Holzbauer S, Dubray C, Guillaumot L, Griggs A, Bel M, Lambert AJ, Laven J, Kosoy O, Panella A, Biggerstaff BJ, Fischer M, Hayes EB (2009) Zika outbreak on Yap Island, Federated States of Micronesia. N Engl J Med 360: 2536-2543.

6. Musso D, Nilles EJ, Cao-Lormeau VM (2014) Rapid spread of emerging Zika virus in the Pacific area. Clin Microbiol Infect 20: O595- O596.

7. Clouet-Huerta D, Alfaro-Toloza P, Rodriguez-Morales AJ (2014) Chikungunya en las Américas: Preparación, vigilancia y alerta en Chile. Rev Chilena Infectol 31: 761-762.

8. Rodriguez-Morales AJ (2015) No era suficiente con Dengue y Chikungunya: llegó también Zika. Archivos de Medicina 11 (in press).

9. Alfaro-Toloza P, Clouet-Huerta DE, Rodríguez-Morales AJ (2015) Chikungunya, the emerging migratory rheumatism. Lancet Infect Dis 15: 510-512.

10. Rodríguez-Morales AJ, Paniz-Mondolfi AE (2015) Venezuela: far from the path to dengue and chikungunya control. J Clin Virol 66: 60-61.
11. Musso D, Roche C, Robin E, Nhan T, Teissier A, CaoLormeau V-M (2015) Potential Sexual Transmission of Zika Virus. Emerg Infect Dis 21: 359-361.

12. Foy BD, Kobylinski KC, Foy JLC, Blitvich BJ, da Rosa AT, Haddow AD, Lanciotti RS, Tesh RB (2011) Probable nonvector-borne transmission of Zika virus, Colorado, USA. Emerg Infect Dis 17: 880-882.

13. Besnard M, Lastère S, Teissier A, Cao-Lormeau V, Musso D (2014) Evidence of perinatal transmission of Zika virus, French Polynesia, December 2013 and February 2014. Euro Surveill 19: 20751.

14. Musso D, Nhan T, Robin E, Roche C, Bierlaire D, Zisou K, Shan Yan A, Cao-Lormeau VM, Broult J (2014) Potential for Zika virus transmission through blood transfusion demonstrated during an outbreak in French Polynesia, November 2013 to February 2014. Euro Surveill 19: 20761.

15. Summers DJ, Acosta RW, Acosta AM (2015) Zika Virus in an American Recreational Traveler. J Travel Med doi: 10.1111/jtm. 12208 .

16. Dupont-Rouzeyrol M, O'Connor O, Calvez E, Daurès M, John M, Grangeon JP, Gourinat AC (2014) Co-infection with Zika and dengue viruses in 2 patients, New Caledonia, 2014. Emerg Infect Dis 21: 381-382.

\section{Corresponding author}

Alfonso J Rodriguez-Morales

Universidad Tecnológica de Pereira, 660003, Pereira, Colombia.

Email: arodriguez@jidc.org

Conflict of interests: No conflict of interests is declared. 